\title{
Labor Market Institutions, Mobility, and Dualization in the Nordic Countries
}

\section{Jørgen Svalund}

Researcher, Fafo, Institute for Labour and Social Research, Norway ${ }^{1}$

\begin{abstract}
Comparing the Nordic countries, this article examines different combinations of permanent and temporary employment protection legislation, and whether such differences are reflected in patterns of labor market transitions. We find higher levels of transitions from unemployment to temporary contracts in Sweden and Finland, with lax regulation of temporary contracts and strict regulation of permanent contracts. Further, temporary employees are integrated into permanent contracts in countries with lax (Denmark) or strict (Norway) regulation of permanent contracts, while this is not the case in Finland and Sweden. For these countries, the study indicates a certain degree of labor market duality, with low mobility from temporary to permanent employment contracts.
\end{abstract}

\section{KEY WORDS}

Mobility / dual labor markets / segmentation / employment protection legislation / Nordic countries / temporary employment

\section{Introduction}

igh mobility signals possibilities for entering and leaving the labor market in accordance with life course changes, while low mobility suggests few job openings for those trying to enter it (OECD, 1994). Labor market mobility may also be involuntary, and to those who lose their jobs, job stability would be preferred (Kalleberg et al., 2000). The institutional regulation of employment protection, the ease of hiring and firing, is usually put at the center of discussions regarding labor market mobility. In order to create flexibility for firms, several countries have reformed their employment protection legislation (EPL), usually by making it easier to hire employees temporarily (Skedinger, 2010). There is a rather uniform agreement that temporary jobs are inferior to permanent jobs, both concerning job content and job security (Booth et al., 2002; Kalleberg et al., 2000). Combining strict regulations of open-ended contracts with lax regulations of temporary contracts has by some been understood as a dual pathway to a flexible labor market, with safe, well-off permanent employees and a share of unsecure temporary employees providing numerical flexibility for firms. Others understand it as providing a bridge into a more permanent position in the labor market (Atkinson, 1984; Booth et al., 2002; Gash, 2008; Giesecke and Groß, 2003; Polavieja, 2006; Palier and Thelen, 2010).

The aim of this article is to examine the relationship between labor market mobility and EPL. Comparing the Nordic countries, known for relatively high levels of mobility

$\overline{{ }^{1} \text { E-mail: jorgen.svalund@fafo.no }}$ 
(Muffels and Luijkx, 2008; OECD, 2004), and taking their regulatory combinations of permanent and temporary contracts as a point of departure, we consider whether these differences are reflected in patterns of labor market transitions. While the strictness of the overall EPL is thought to influence the transition patterns into the labor market, lax regulation of temporary contracts are by some thought to provide unemployed individuals a bridge into labor markets with strict regulation of permanent contracts, later integrating them into the standard, permanent employment contract. The article therefore investigate whether different regulatory combinations influence unemployed individuals' probability of getting employment through permanent or temporary job contracts, and further whether those temporarily employed stay employed through a temporary or permanent contract, or become unemployed, hence creating a dual labor market. The study has been made possible through pooling the labor force survey (LFS) for these countries for the years 2000-2006.

While there are within-country studies focusing on the consequences of different combinations of temporary and permanent employment contract regulation, there are few comparative studies. Those which exist often compare countries originating in different welfare state nexuses with rather large differences also regarding their industrial relation (IR) systems, unemployment benefit (UB) system, use of active labor market policies, educational systems etc., possibly influencing the consequences EPL institutions have on these transitions. In order to better grasp the influence that EPL might have on the labor markets' ability to integrate workers into permanent contracts, Denmark, Finland, Norway, and Sweden are compared. These countries share similarities in a range of areas (Esping-Andersen, 1990; Magnusson et al., 2008), but show marked differences regarding regulation of permanent and temporary employment contracts.

The OECD EPL index is a much used measure when comparing regulatory strictness across countries (Skedinger, 2010). The index on permanent contracts quantifies (1) procedural inconveniences faced by the employers when initiating the dismissal process, such as notification and consultation requirements; (2) notice periods and severance pay requriements; and (3) difficulty of dismissals, such as the circumstances in which it is possible to dismiss workers and the consequences if a dismissal is later found to be unfair. The index on temporary contracts quantifies (1) regulation on fixed-term and temporary work agencies contracts, such as the work for which these contracts are allowed, and their duration; (2) the regulation governing temporary work agencies; and (3) requirements for agency workers to receive the same pay and/or conditions as equivalent workers in the user firm (Venn, 2009: 6).

According to the index, ranging from 0 to 6 with 6 being the strictest, Denmark had a liberal legislation on both temporary and permanent contracts, not only compared with the other Nordic countries but also relative to other OECD countries (OECD mean represented by dotted lines) (Figure 1). Norway had strict regulation on temporary employment and quite strict regulations of permanent contracts, while Sweden had a rather slack regulation on temporary employment and the strictest regulation of permanent contracts. While these countries represent different institutional combinations, Finland is placed somewhat in between, near the OECD mean (Figure 1). The comparison thus allows us to study the link between these countries' institutional arrangements regarding EPL and the structure of their labor market transitions.

This article is organized as follows: first, a discussion on EPL and the possible connections between these institutions and entry into, and integration in, the labor 
Figure I: Regulation of permanent and temporary employment in the Nordic countries: OECD index 2005.

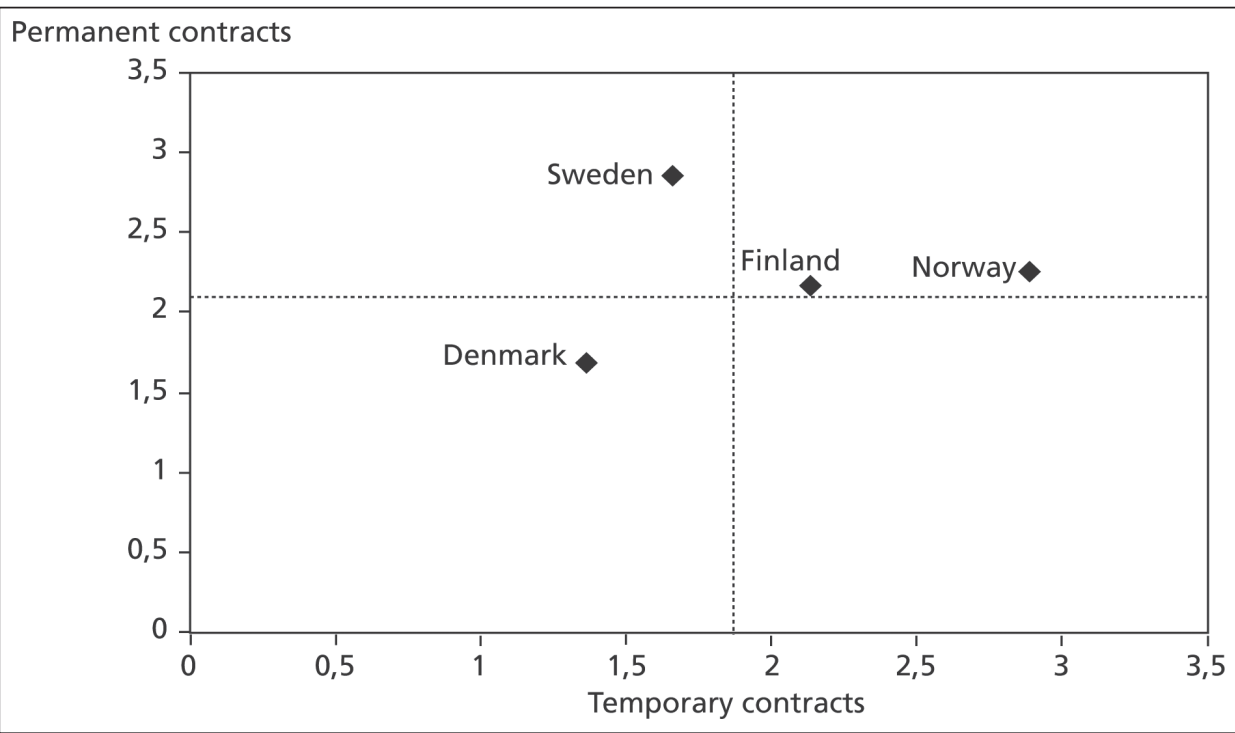

Note: There were only few changes in the OECD index for these countries during the period 2000-2007 (Venn, 2009). The dotted lines represent the OECD mean. The Figure was changed October 2013. Some of the figures had unfortunately been mixed up. The change does not influence the content of the article in any way.

market, is presented. The discussion and the country differences further leads into some expectations. Second, the challenges and difficulties faced when making a cross-country analysis of this sort is discussed. We then describe the data and methods to be used in the analysis. Fourth, we present the results with controls for country differences. Finally, the results and their implications for the understanding of such regulations are discussed.

\section{Labor market mobility and employment protection regulation}

While neoclassical economics perceive the (ideal) labor market as free and unregulated, and employment contracts between employers and employees as beneficial for both parties, public regulations and collective agreements structure the use and content of employment contracts in real-life labor markets (Esping-Andersen and Regini, 2000b; Rubery and Grimshaw, 2003). Differences in the strictness of EPL between countries may lead to differences in labor mobility from unemployment to permanent or temporary employment, and in the integration of temporary employees into permanent contracts (Chung, 2005; Gash, 2008; Giesecke and Groß, 2003). The regulation of permanent and temporary contracts can be combined in three ways.

First, both permanent and temporary contracts can be laxly regulated. With lax regulation of permanent contracts, the employers' need for temporary employees is 
reduced, as "permanent" contracts are flexible for employers (Chung, 2005: 37). While this implies high mobility and high use of permanent contracts, there is a limit to how lax the regulation can be. Commitment, trust, cooperation and long-term horizon are often important in the employer-employee relationship, and to stimulate this in countries with lax regulations, companies may initiate in-house regulations on seniority or severance pay, while other hidden rigidities may be anchored in collective agreements at various levels (Edlund and Grönlund, 2008; Esping-Andersen, 2000: 71; Jensen, 2011; Regini, 2000: 23).

Second, lax regulations imply unstable employment relations, thus low job and income security (Burroni and Keune, 2011; Howell et al., 2007; Ozaki, 1999). In order to balance employer flexibility against job and income security, both permanent and temporary contracts can be strictly regulated. According to economic theories, strict EPL in labor markets with wage floors will reduce employers' ability to lay off workers and their incentives to employ new or more workers (Lazear, 1990), resulting in lower mobility and fewer opportunities for those trying to enter the labor market (Bentolila and Bertola, 1990; Gangl, 2003). As lower employer flexibility increases the hiring risks, such a combination may reduce the opportunities for those with marginal labor market connection. Research indicates that strong EPL increases the unemployment level for youth, immigrants, and women (Bertola et al., 2007; Esping-Andersen, 2000; Feldmann, 2003; Heckman and Pages, 2000; OECD, 2004, 2008). As a response to high unemployment in some European labor markets, and to address the expected lower mobility in the labor market, some argue that strictly regulated labor markets should be deregulated, in line with the lax regulation mode (Esping-Andersen and Regini, 2000a). Still, research on EPL stringency shows no impact on the overall unemployment level (Esping-Andersen, 2000; Heckman, 2007; Howell et al., 2007; OECD, 2008). Further, a comparison of mobility from unemployment to employment in the Nordic countries, using the same data as this article, finds that the transition rates from unemployment to employment (temporary or permanent) are highest in Norway, followed by Denmark, Sweden, and Finland (Berglund and Furåker, 2011). Explaining results that oppose the neoclassical economic view, Regini (2000: 23) points to the fact that there traditionally exists "hidden flexibilities" alongside strict official regulations, where actors negotiate more flexible solutions to hiring and firing issues on firm or industry level. For instance, a case study of labor adjustments in manufacturing companies in the Nordic countries after the economic crisis of mid-2008 (Svalund et al., 2013) finds that the local parties in Norway and Sweden negotiated solutions that enabled more flexible adjustments than stated in the formal regulations, showing a certain level of discretion when applying the dismissal regulations. Therefore, strict labor markets may still provide high mobility and employment possibilities. Contrary to lax regulation, such a combination implies a low probability of a transition from unemployment to employment through temporary employment. Further, as in the third regulatory mode (see below), temporary contracts may integrate temporary employees into standard contracts or lead to segmented labor markets on a limited scale (due to the restrictions on the use of temporary employees).

Third, as relaxing the regulations on permanent contracts faces employee opposition in numerous European labor markets, another way to relax the EPL is to combine strict regulations of permanent contracts with lax regulations of temporary contracts (partial deregulation). Lenient regulation of temporary contracts may provide employers the possibility of adjusting personnel needs to economic fluctuations or changes in technology and 
production, while offering unemployed individuals a bridge (Gash, 2008) into the labor market, possibly integrating them on a longer term (Giesecke and Groß, 2003). Hence, temporary contracts can function as a probationary contract where the employers in practice screen employees before offering a permanent contract (Booth et al., 2002; Gash, 2008), thus reducing hiring risks. While proponents of this combination claim that the entry of unemployed through temporary contracts, and the integration of temporary employees into permanent contracts in the longer run, does not lead to labor market segmentation or dualism, critics claim it does. Segmentation and dualism theories (Boje, 1986; Hodson and Kaufman, 1982; Kalleberg and Sørensen, 1979) predict clear differences between core and periphery segments, here by way of employment contract. Type-of-contract segmentation theory (Gash, 2008; Giesecke and Groß, 2003; Polavieja, 2003) asserts that while the insiders have permanent contracts and secure jobs, the outsiders have temporary contracts and insecure jobs. These theories predict reduced transitions from temporary to permanent contracts in such labor markets, and higher transitions from temporary contracts to unemployment. While the core workers, with permanent contracts, have a privileged position in such a regulatory system, it may create incentives for firing temporary workers even when they are productive just to avoid them becoming insiders (Blanchard and Landier, 2002).

There exist several within-country studies analyzing the consequences of these different regulatory combinations. Hagen (2003) finds that temporary work leads to permanent work in West Germany, while Giesecke and Groß (2003), studying Germany, find temporary workers more likely than permanent workers to become unemployed. In a Nordic context, two analyses from Norway show that a majority of temporary employees who stayed employed ended up on a permanent contract during a two-year (Nergaard, 2004) or four-year (Skollerud, 1997) period. Håkansson (2001) and Levin (1998), studying Sweden during the 1990s, both found that temporary employees at time $t$ had a higher risk of becoming unemployed two years later compared to those with permanent employment, but lower risks than those unemployed at time $t$. Also Nätti (1993), studying Finland, found that temporary employment functioned as a trap for those previously unemployed, as every third temporary employee felt under threat of unemployment, compared with $9 \%$ of the permanent employees. While these studies show that there are some integration of temporary employees into permanent positions, a disadvantage of these within-country studies is that it is difficult to assess whether the transition rates from unemployment to permanent or temporary employment, or from temporary employment to further employment or unemployment, are high or low relative to other countries, perhaps with differences in labor market composition.

There are few relevant comparative studies with individual micro-data able to control for differences in labor market composition. Gash (2008) had such data and compared Denmark (mode 1), West Germany (mode 2), France (mode 2), and the UK (mode 1), and investigated whether different institutional set-ups integrate temporary employees into the standard contract. When comparing the relative rates of transition from temporary employment to either permanent employment or unemployment, she found strong differences by country with West Germany, the strictest of these countries on the OECD EPL ranking, providing temporary employees the best chances of obtaining a permanent contract relative to entering unemployment (Gash, 2008: 663). As such, an important contribution of this article will be to compare the relative transition rates of the Nordic countries, and their regulatory combinations, while controlling for differences in labor market composition. 


\section{Hypotheses}

The general hypotheses that can be derived from the above discussion, where the neoclassical idea about free, lax, and flexibly regulated labor markets is contrasted with a stricter regulatory mode more focused on employment security, and a combinatory mode where strict protection of permanent employees are combined with lax regulation of temporary contracts, are as follows:

1. Since regulation of permanent contracts is strictest in Sweden, followed by Norway, Finland, and Denmark, the hiring risks and need for screening should follow this regulatory pattern. But as the use of temporary contracts is also regulated, the relative transition rates from unemployment to temporary contracts rather than permanent should be highest in Sweden, followed by Finland, Norway, and Denmark.

2. The lax regulations of permanent contracts in Denmark should reduce the hiring risks; thus temporary contracts should mostly be used for temporary jobs, timelimited projects, etc., increasing the probability of transitions from temporary employment to unemployment.

a. Following the proponents of lax temporary regulations, there should be low transition rates from temporary contracts to unemployment, while the transition rates from temporary to permanent employment should be high in all countries.

b. Those claiming that temporary employment will lead to segmentation expect high rates of transitions from temporary employment to unemployment, or to temporary rather than permanent contracts, in countries where strict regulation of permanent contracts are combined with lax regulation of temporary contracts; thus, the transition rates should be highest in Sweden, followed by Finland and Norway.

\section{Comparing EPL and labor market transitions in the Nordic countries}

\section{Measuring EPL}

Measuring EPL strictness nationally has some important limitations when permanent and temporary contracts are regulated in a combination of law and collective agreements, as in the Nordic countries. While the OECD index incorporates collective agreements alongside legislation (Venn, 2009), extensive use of collective agreements rather than legislation opens up for more variation in the EPL level between industries and workers within a country. This is especially pronounced in Denmark, where white-collar workers are covered by the Law on Salaried Employees (Funktionærloven) or collective agreements with terms fairly equal to the law, stipulating stricter terms than among workers, where employers generally can dismiss easily, without much advance notification (Berglund et al., 2010: 229-238; Jensen, 2011: 276). Therefore, as all comparative analysis, quantifying and comparing across countries reduces complexity. Even though the index is a crude measure, it does provide an important assesment refined over years, and there are no comparative indicator that is considered better. 


\section{Institutional differences that might influence mobility patterns}

This comparison is based on a "most similar" design (Ragin, 1987: 48), where the cases are rather similar in all but some few respects. Still, there are important differences between the countries that might influence the mobility patterns. Consequently, we should be cautious to interpret between-country differences in labor market outcomes solely to EPL differences. Differences in institutional structures related to the labor market, such as UB, as well as the educational and pension systems, may influence the supply of labor moving into and out of temporary and permanent employment.

A generous UB may reduce the job search intensity and make the unemployed less willing to accept "just any" job (OECD, 2006: 56). Unemployment insurance coverage is mandatory in Norway and voluntary (Ghent system) in the other Nordic countries. Uninsured unemployed must resort to means-tested social assistance in Sweden and Denmark, while there is a UB II system with benefits above the social assistance level in Finland (Dølvik et al., 2011), implying that search intensity for the uninsured was higher in Denmark and Sweden, perhaps making them more prone to accept temporary employment. There were only minor country differences in UB generosity in the years 2000-2006 for those insured (OECD, 2007: tables 3.1 and 3.2), where the Danish system was more generous on low income levels, along with Sweden, compared with Finland and Norway. Nickell (1997) argues that it is the duration of the UB that has an impact on the transition rate from unemployment to employment, since the probability of a transition into employment increases as unemployed persons approach the duration limit. The maximum duration was longest in Denmark (48 months), compared with $36^{1}$ months in Norway, 28 months in Sweden, and 24 months in Finland (Berglund et al., 2010: 45). Summing up, the differences in the Nordic UB systems should imply that the mobility out of unemployment is lower in Denmark than it otherwise would have been. This is due to Denmark's high level of replacement rate at low levels and the lengthy duration, compared with the other Nordic countries, perhaps making insured unemployed less prone to accept temporary employment.

Further, while the normal retirement age is considered to be 65 years in the Nordic countries, there are differences between these countries regarding early retirement options (Dølvik et al., 2011). At the time of the study, Denmark had an early retirement allowance ("after wage"), enabling workers to retire from the age of 55, but with lower allowance for those retiring before the age of 62 (Goul Andersen, 2007). In Finland, the unemployed who turned 60 before the 500-day period of UB was over could move directly into old age pension. In Norway, a collectively agreed supplementary pension scheme allowed covered groups to retire at the age of 62 , while in Sweden there was no such early retirement system. These differences may imply that individuals facing early retirement may transit from unemployment or temporary employment to a position outside the labor market, rather than to (further) employment one year later.

The level of unemployment, growth, or decline in employment at large may also affect the mobility patterns (Andersen et al., 2008; Blanchard and Portugal, 2001). A central mechanism in labor market adjustment in the Nordic countries has been to facilitate a dynamic interplay between market competition, solidaristic wage policies, and active labor market policies (Barth et al., 2009; Erixon, 2010; Ibsen, 2011; Meidner 
and Rehn, 1953; van den Berg, 2008). Less productive firms unable to match the wage floor defined through centralized agreements are forced out of competition, while the redundant workers, facilitated by public training, mobility schemes, and UBs, move into new jobs in more productive companies. Therefore, mobility is governed primarily by labor demand at the company level. High labor demand creates high mobility rates into employment, hence a full employment model has little room for insider-outsider labor markets (DiPrete et al., 2001). When labor demand is lower, the probability for reemployment (job-to-job mobility) is lower, and the probability for mobility into unemployment increases. If temporary employment leads to higher mobility into unemployment, the transition rates should be higher in case of low labor demand.

The unemployment and employment rates and the rate of growth in employment differed across the countries in the period. Finland had an unemployment rate of more than $10 \%$ in 2000, decreasing to below $7 \%$ in 2007, the same as Sweden in 2007. While Denmark had lower figures the whole period (around 5\%), Norway had the lowest figures (Table 1). There were only minor differences in employment growth in these years,

Table I Unemployment rates, employment rates, and growth: 2000-2006. Average percentage points 15-64.

\begin{tabular}{lcccc}
\hline & Unemployment & Employment & Share of temporary employees & Employment growth \\
\hline Denmark & 4.7 & 76.1 & 9.5 & 3.4 \\
\hline Finland & 8.8 & 68.1 & 17.2 & 4.6 \\
\hline Norway & 3.8 & 73.0 & 9.8 & 4.3 \\
\hline Sweden & 6.6 & 76.0 & 15.6 & 4.5 \\
\hline
\end{tabular}

Source: Eurostat (EU-LFS).

highest in the countries having the lowest employment to population ratio, and the highest unemployment ratio (Table 1).

While focusing on labor market transitions (mobility), the actual level or stock of temporary contracts as a percentage of all employees at a given time varies between these countries during 2000-2006, with around 10\% of all employees aged 15-64 years temporarily employed in Denmark and Norway, compared with approximately $16 \%$ in Sweden and 17\% in Finland (Berglund et al., 2010: 34). Still, differences in transition patterns and thus the duration of the temporary contracts between countries may mean that the level of temporary employment and the transition rates in and out of this position are only modestly connected.

\section{Data and method}

The data are from the LFS for the years 2000-2007 for Finland, Norway, and Sweden and from 2000 to 2006 in Denmark. As noted, the employment grew during these years, while the unemployment and employment rates showed steady changes. In the years after, the financial and economic shift has impacted these countries' employment and 
unemployment rates, as well as economic growth, with rather different strengths (Jochem, 2011). The article therefore concentrates on these rather stable years. The data consist of a representative sample of the population in these countries aged 16-63, a total of 420,567 persons. The respondents were all surveyed at two points in time, with one year between. As an example, we therefore have information about an individual's labor market status the first quarter of $2000(t)$ and the first quarter of $2001(t+1)$. It is therefore possible that the individuals followed have changed status several times within the year, without it being recorded in the data. As the data only measure change between two points in time, we cannot control for individual heterogeneity as a longitudinal study would allow. Still, using a pooled dataset, we are able to control for compositional differences in the labor force, such as differences in age and gender composition, industry structure, company size, or differences in economic shifts, something that has not been done in previous studies of the Nordic countries. While the pooled data and the logistic analysis do allow control for compositional and structural differences between these labor markets, the data and method do not provide an opportunity to separate the effect of EPL on its own and the effect of other (institutional) differences between these countries. Therefore, the aim of this study is to investigate whether the mobility patterns in focus resemble the theoretical expectations brought forward in labor market theories, without claiming that all between-country variation is caused by EPL differences.

Focusing on whether and how different combinations of EPL may influence mobility patterns from unemployment and into the labor market, Table 3 use a dependent variable that measures whether those unemployed at $t$ and employed at $t+1$ made this transition into a permanent (value 0 ) or a temporary (value 1) contract. Investigating whether temporary employees become integrated into the labor market, Table 4 analyze whether temporary employees stay employed at $t+1$ or change status into unemployed. Table 4 also analyze transitions from permanent contracts to unemployment, comparing whether high levels of transitions from temporary employment to unemployment influence the rate of transitions from permanent contracts to unemployment, and vice versa. Staying employed in a temporary or permanent contract is given the value 0 , while a transition into unemployment is given the value 1 . Finally, integrating temporary employees into the labor market may also mean that temporary employees get a permanent contract. In Table 5 the probability that those temporarily employed at $t$ and still employed at $t+1$ hold a temporary (value 0 ) rather than a permanent (value 1 ) contract is studied.

A proportion of the population in all labor markets is not in the labor force, due to military service, maternity leave, child caring responsibilities, education, disability pension, etc. There are some transitions from this status to the labor market from one year to the next, but this group consists of individuals in very different positions. We therefore focus on unemployed persons, who are a more unified group that we expect tries to enter the labor market. Transitions from temporary employment to unemployment are also easier to interpret as involuntary movements, compared with forms of transitions into inactivity.

Mobility rates tend to differ between different age groups, as young individuals make labor market transitions to a higher degree than older individuals. Comparing different labor markets, differences in age composition between the countries may influence the mobility rates (Andersen et al., 2008). Norway and Denmark have a higher proportion of young individuals participating in the labor market, and ceteris paribus, the mobility 
rates can be expected to be higher. This difference may be caused, for example, by differences in the labor demand, in the educational system, or in the possibilities of getting a part-time job while studying (Gangl et al., 2003; Olofsson and Wadensjö, 2007). As mentioned, there are also differences in the pension systems, possibly influencing the participation of those in the older age groups (Hult and Edlund, 2008). In order to avoid that such differences influence the results, we have analyzed both the whole group (19-63 years) and individuals in their prime labor market age (25-54 years).

We use logistic regressions where transition rates for each country are compared with the Nordic mean. By comparing all the countries in one regression analysis, we are able to control for differences in labor markets, be it labor market composition or structural factors. We control for a range of factors: demographic variables, gender, age, area of origin, and education are included. In the analysis of transitions from temporary or permanent employment to either employed or unemployed (Table 4), and from temporary to still temporary or permanent employment at $t+1$ (Table 5 ), several variables that are centered on the individuals' connection with the labor market are used. Patterns of mobility into temporary or permanent employment and from temporary to permanent employment vary between different industries. We therefore control for differences in composition of the industries (NACE 2 digit level), company size, occupational structure (ISCO-88 2 digit level), and working time. Structural and cyclical conditions in the labor market are also controlled for. Following Berglund et al. (2010), we control for structural factors that might affect the mobility rates through a variable that measures the county unemployment rates. In the analyses, the county unemployment rate variable is divided into high, medium, and low relative to the county mean unemployment level of the Nordic countries as one (see Berglund et al., chapter 4 for more details). Economic cycles are also controlled for through a variable that measures changes in national unemployment levels in percent from one year to the next.

\section{Results}

Comparing country differences in distribution of the independent variables (table not shown here), there are mostly small differences. Worth noticing is that the variation in county unemployment level and change in national unemployment vary rather strongly across the Nordic countries, with lower levels and variation in Denmark and Norway.

In Table 2 descriptive data on what happened to the unemployed individuals from one year $(t)$ to the next $(t+1)$ and whether they were still unemployed, had made a transition to inactivity, or were permanently or temporarily employed, are presented. Further, we describe whether those temporarily and permanently employed at $t$ had changed status one year later and had made a transition to either permanent or temporary employment, unemployment, or inactivity.

Table 2 reveals distinct country differences concerning the transition rates from unemployment at $t$ to inactivity, permanent employment, and temporary employment one year later. The proportions of unemployed individuals at $t$ who are still unemployed at $t+1$ are much higher in Finland and Sweden, compared with Denmark and especially Norway: $21 \%$ in the age group 19-63 years were still unemployed one year later in Norway, compared with $37-38 \%$ in Finland and Sweden; $59 \%$ of the unemployed at $t$ make a transition into employment one year later in Norway, compared with $48 \%$ 
Table 2 Change in employment status from one year to the next. Unemployed and temporarily employed at $t$ : 19-63 and 25-54 years of age, by country, 2000-2007. Percent.

\begin{tabular}{lcccccccc}
\hline & \multicolumn{2}{c}{ Denmark } & \multicolumn{2}{c}{ Finland } & \multicolumn{2}{c}{ Norway } & \multicolumn{2}{c}{ Sweden } \\
\cline { 2 - 8 } Age group & $19-63$ & $25-54$ & $19-63$ & $25-54$ & $19-63$ & $25-54$ & $19-63$ & $25-54$ \\
\hline Unemployed at $t$ & & & & & & & & \\
Status at $t+1$ & & & & & & & & \\
Unemployed & 29.1 & 27.2 & 38.0 & 37.4 & 20.8 & 20.3 & 37.8 & 34.1 \\
Inactive & 23.2 & 17.6 & 23.8 & 19.9 & 20.7 & 19.6 & 18.1 & 17.6 \\
Permanent employed & 31.9 & 37.5 & 15.2 & 17.4 & 42.8 & 43.5 & 20.0 & 22.7 \\
Temporary employed & 15.8 & 17.7 & 22.9 & 25.3 & 15.6 & 16.6 & 24.2 & 25.6 \\
\hline$N$ & 4251 & 3178 & 5859 & 4923 & 1130 & 1008 & 4818 & 3812 \\
\hline
\end{tabular}

Permanent employed at $t$

Status at $t+1$

\begin{tabular}{lcccccccc} 
Permanent employed & 91.5 & 92.8 & 91.9 & 94 & 93.9 & 94.3 & 89.9 & 95.5 \\
Temporary employed & 2.5 & 2.7 & 2.4 & 1.9 & 2.4 & 2.0 & 2.2 & 2.0 \\
Unemployed & 2.3 & 2.1 & 1.3 & 1.2 & 1.2 & 1.1 & 1.3 & 1.2 \\
Inactive & 4.7 & 2.5 & 4.8 & 2.9 & 4.6 & 2.6 & 2.6 & 1.4 \\
\hline $\mathrm{N}$ & 46705 & 35861 & 79995 & 61947 & 43387 & 32228 & 93748 & 70124 \\
\hline Temporary employed at $t$ & & & & & & & & \\
Status at $t+1$ & & & & & & & & \\
Temporary employed & 30.9 & 31.3 & 51.7 & 52.4 & 30.4 & 31.0 & 48.5 & 47.5 \\
Permanent employed & 44.4 & 46.2 & 26.4 & 27.2 & 54.6 & 55.0 & 34.3 & 36.4 \\
Unemployed & 11.8 & 11.3 & 11.3 & 10.8 & 4.6 & 4.7 & 8.0 & 7.5 \\
Inactive & 12.9 & 11.2 & 10.6 & 9.6 & 10.4 & 9.3 & 9.2 & 8.6 \\
\hline $\mathrm{N}$ & 4042 & 3478 & 8917 & 8277 & 2728 & 2514 & 8400 & 8277 \\
\hline
\end{tabular}

Note: The period for Denmark is 2000-2006.

in Denmark, $44 \%$ in Sweden, and $38 \%$ in Finland. As such, the mobility rates from unemployment to employment are much lower in Finland and Sweden, compared with Denmark and Norway. While unemployed in Norway and Denmark to a large part move into permanent employment one year later, this is not the case in Finland and Sweden. In those countries, a higher proportion move into temporary rather than permanent employment. There are few significant differences between the whole group and 
those in the prime age. A lower proportion of those in the prime age make a transition to inactivity in Denmark and Finland, while there are no such differences in Sweden and Norway. Further, a higher share of prime age individuals makes a transition to a permanent contract in Denmark. Finally, the total level of transitions from unemployment to employment, regardless of path, is much higher among prime age individuals than in the whole group in Denmark (6\% difference) and in Finland (4\% difference), compared with 3\% difference in Sweden and 1\% in Norway.

Turning to those permanently employed at $t$, most have the same status at $t+1$. While Sweden has the lowest stability (90\%), Norway has the highest $(94 \%)$. While just above $2 \%$ change status into temporary employment in all the Nordic countries, a somewhat higher share in Denmark move into unemployment, compared with the other Nordic countries. Further, a lower share makes a transition into inactivity in Sweden, compared with the other Nordic countries. Comparing the whole group with those in the prime employment age, the stability among those in the prime age is much higher in Sweden than in the whole group and compared with the prime age group in the other Nordic countries. Finally, Table 2 shows that the transition rate from permanent employment to inactivity, as could be expected, is much higher in the whole group.

The mobility rates out of temporary employment are much higher in Denmark and Norway, compared with Finland and Sweden. The transition rate from temporary to permanent employment contracts is twice as high in Norway, compared with Finland. Instead, higher proportions stay temporarily employed in Finland and Sweden. There are also differences in transition rates between the Nordic countries concerning transitions to unemployment. While $5 \%$ in the whole group were still unemployed at $t+1$ in Norway, $8 \%$ were unemployed in Sweden, compared with $11 \%$ in Finland and $12 \%$ in Denmark. A higher share move from temporary contracts to inactivity in Denmark compared with the other countries, while there are no differences between the whole group and those in the prime age.

\section{Pathways from unemployment to employment-through a permanent or a temporary contract?}

Berglund and Furåker (2011), using the same data as this article, find that the transition rates from unemployment to employment (temporary or permanent) are highest in Norway, followed by Denmark, Sweden, and Finland. While the level of mobility is important, our focus is on the pathways into the labor market. In what way do these go through temporary employment? Logistic regressions are used to analyze the crossnational differences regarding the dependent variables at the center of this article. First, do we find country differences in the transition from unemployment to either temporary or permanent employment contracts in the Nordic countries?

The probability of making a transition from unemployment at $t$ to a permanent rather than temporary contract at $t+1$ is higher than the Nordic mean in Norway and Denmark, while it is lower in Sweden and Finland (Table 3). In order to rule out the influence of differences in the educational or retirement systems, a separate analysis for those in the 25-54 age group has been made. The analysis shows the same general pattern for both age groups, but the probability of making a transition into temporary employment is lower 
Table $\mathbf{3}^{2}$ Binominal logistical regression of labor market transitions from unemployment to either permanent $(=0)$ or temporary (=1) employment contracts: 2000-2007.

\begin{tabular}{|c|c|c|c|c|c|}
\hline \multirow[b]{2}{*}{ Age group } & \multirow[b]{2}{*}{$\begin{array}{l}\text { Country (ref }= \\
\text { means of odds) }\end{array}$} & \multicolumn{2}{|c|}{ Model I } & \multicolumn{2}{|c|}{ Model 2} \\
\hline & & $b$ & S.E. & $b$ & S.E. \\
\hline \multirow{6}{*}{ 19-63 } & Denmark & $-0.533 * * * *$ & $0.04 I$ & -0.486 **** & 0.045 \\
\hline & Finland & $0.644 * * * *$ & 0.036 & $0.420 * * * *$ & 0.049 \\
\hline & Norway & -0.690 ***** & 0.057 & -0.459 **** & 0.069 \\
\hline & Sweden & $0.579 * * * *$ & 0.037 & $0.525 * * * *$ & 0.039 \\
\hline & Pseudo $R^{2}$ & 0.117 & & 0.123 & \\
\hline & $N$ & & & & 9512 \\
\hline \multirow{6}{*}{$25-54$} & Denmark & -0.540 ***** & 0.049 & $-0.515 * * * *$ & 0.054 \\
\hline & Finland & $0.668 * * * *$ & 0.045 & $0.469 * * * *$ & 0.061 \\
\hline & Norway & $-0.62 I^{\text {****** }}$ & 0.072 & $-0.388 * * * *$ & 0.087 \\
\hline & Sweden & $0.493 * * * *$ & 0.047 & $0.435 * * * *$ & 0.049 \\
\hline & Pseudo $R^{2}$ & 0.125 & & 0.130 & \\
\hline & $N$ & & & & 6003 \\
\hline
\end{tabular}

Note: The period for Denmark is 2000-2006. Significance probabilities for the coefficients: $* * * p<0.00$ I, $* * p<0.0$ I, * $p<0.05$.

Controls have been conducted regarding gender, age, educational level and area of origin in model I, while we have also controlled for relative county unemployment levels and annual national changes in unemployment levels in model 2.

in Finland and Denmark in model 2 than for the whole group. The main picture in Table 3 is that the probability of making a transition from unemployment to employment via a temporary contract is higher than the Nordic mean in Sweden and Finland, while it is lower in Denmark and Norway.

\section{Integrating temporary employees-Temporary and permanent employees' probability of staying employed}

To investigate whether temporary employees become integrated in the labor market, logistic regressions are used to analyze the cross-national differences in the transition rates from temporary employment to either staying employed or changing status to unemployed. We also study whether those permanently employed at $t$ stay employed or change status to unemployed, investigating whether higher transition rates out of temporary employment are followed by lower transition rates out of permanent employment, and vice versa.

A main focus in this article is to study whether those temporarily employed at $t$ remain employed or have a higher probability of becoming unemployed at $t+1$. Turning 
to these transitions for the whole group in Table 4, model 1, the probability of becoming unemployed is highest in Finland, followed by Denmark, with Sweden next, just below the Nordic mean. The probability is lowest in Norway, far below the Nordic mean. The results for those in the prime age are rather comparable, even though the probability of changing status to unemployed then are highest in Finland, with Denmark second. When controlling for labor market structures in model 2, the transition rate out of temporary employment is highest in Finland and then Denmark, while the probability is still the lowest in Norway.

Studying both age groups, and controlling for all intervening factors except the labor market variables (model 1), Denmark also has the highest transition rates from permanent employment to unemployment, while Norway has the lowest. Finland and Sweden have figures close to the Nordic average. When controlling for the relative unemployment

Table 4 Binominal logistical regression of labor market transitions from permanent or temporary employment at $t$ to still employed $(=0)$ or unemployed $(=1)$ at $t+1$ : 2000-2007.

\begin{tabular}{|c|c|c|c|c|c|c|c|c|c|}
\hline & & \multicolumn{4}{|c|}{ Permanently employed at $t$} & \multicolumn{4}{|c|}{ Temporary employed at $t$} \\
\hline & & \multicolumn{2}{|c|}{ Model I } & \multicolumn{2}{|c|}{ Model 2} & \multicolumn{2}{|c|}{ Model I } & \multicolumn{2}{|c|}{ Model 2} \\
\hline $\begin{array}{l}\text { Age } \\
\text { group }\end{array}$ & $\begin{array}{l}\text { Country } \\
\text { (ref= means } \\
\text { of odds) }\end{array}$ & $b$ & S.E. & $b$ & S.E. & $b$ & S.E. & $b$ & S.E. \\
\hline \multirow{6}{*}{ 19-63 } & Denmark & $0.477 * * * * *$ & 0.029 & 0.479**** & 0.032 & $0.194 * * * *$ & 0.044 & $0.201 * * * *$ & 0.048 \\
\hline & Finland & $-0.102 * * * *$ & 0.031 & -0.203 ***** & 0.042 & $0.326 * * * *$ & 0.037 & $0.177 * * * *$ & 0.049 \\
\hline & Norway & -0.284 **** & 0.038 & $-0.113^{*} * * *$ & 0.047 & $-0.438 * * * *$ & 0.060 & $-0.224 * * * *$ & 0.071 \\
\hline & Sweden & -0.090 ****** & 0.028 & $-0.163^{*} * * *$ & 0.030 & $-0.082 * *$ & 0.038 & -0.153 ***** & 0.040 \\
\hline & Pseudo $R^{2}$ & \multicolumn{2}{|l|}{0.06} & \multicolumn{2}{|l|}{0.06} & \multicolumn{2}{|c|}{0.07} & \multicolumn{2}{|l|}{0.08} \\
\hline & N & \multicolumn{4}{|c|}{234,691} & \multicolumn{4}{|c|}{25,477} \\
\hline \multirow{6}{*}{$25-54$} & Denmark & $0.505^{* * * *}$ & 0.035 & 0.498**** & 0.038 & $0.357^{* * * * *}$ & 0.054 & $0.365 * * * *$ & 0.059 \\
\hline & Finland & $-0.097^{*} * * *$ & 0.037 & $-0.187^{* * * * *}$ & 0.050 & $0.323 * * * *$ & 0.047 & $0.162 * * * *$ & 0.063 \\
\hline & Norway & $-0.27 \mid$ ****** & 0.046 & $-0.098 * * * *$ & 0.057 & $-0.553^{*} * * *$ & 0.080 & $-0.332 * * * *$ & 0.095 \\
\hline & Sweden & $-0.137^{* * * * *}$ & 0.034 & -0.212 ***** & 0.036 & -0.127 *** & 0.049 & $-0.194 * * * *$ & 0.051 \\
\hline & Pseudo $R^{2}$ & \multicolumn{2}{|l|}{0.05} & \multicolumn{2}{|l|}{0.06} & \multicolumn{2}{|c|}{0.09} & \multicolumn{2}{|l|}{0.09} \\
\hline & N & \multicolumn{4}{|c|}{181,198} & \multicolumn{4}{|c|}{16,706} \\
\hline
\end{tabular}

Note: The period for Denmark is 2000-2006. Significance probabilities for the coefficients: $* * * *<0.00$ I, $* * p<0.0$ I, $* p<0.05$. Controls regarding gender, age, educational level, area of origin, industry, occupation, and working time are conducted in model I, while relative county unemployment levels and annual national changes in unemployment levels are also added in model 2. 
level and changes in the unemployment level the last year (model 2), the patterns change somewhat for individuals in their prime age. While the order is still the same, Norway now also has figures close to the Nordic mean.

\section{Integrating temporary workers-Temporary employees' probability of moving into permanent contracts}

As temporary jobs are inferior regarding quality of working life, training, etc., integrating temporary employees into the labor market is not just about whether those holding such contracts stay employed, but also whether they move on to permanent contracts over time. We therefore also make a cross-national analysis of whether those temporarily employed at $t$, and still employed at $t+1$, are still temporarily employed or have moved on to a permanent contract at $t+1$ (Table 5 ).

Both models in Table 5 show that for those staying employed from $t$ to $t+1$, the probability of making a transition from temporary to permanent employment is highest in Norway, followed by Denmark. While the probability of such transitions is higher than the Nordic mean in these countries, it is lower than the Nordic mean in Sweden and lowest in Finland. There are only minor differences between the whole group and those in their prime age. Most notable is the fact that the transition rate for the prime age group is almost the same in model 2 for Denmark and Norway.

Table 5 Binominal logistical regression of labor market transitions from temporary employment at $t$ to temporary (0) or permanent ( I) employment at $t+1$ : 2000-2007.

\begin{tabular}{|c|c|c|c|c|c|}
\hline \multirow[b]{2}{*}{ Age group } & \multirow[b]{2}{*}{ Country (ref= means of odds) } & \multicolumn{2}{|c|}{ Model I } & \multicolumn{2}{|c|}{ Model 2} \\
\hline & & $b$ & S.E. & $b$ & S.E. \\
\hline \multirow{6}{*}{ 19-63 } & Denmark & $0.339 * * * *$ & 0.029 & 0.327 米米 & 0.031 \\
\hline & Finland & -0.743 米米 & 0.024 & $-0.627 * * * *$ & 0.032 \\
\hline & Norway & 0.710 ***** & 0.032 & 0.577 ***** & 0.039 \\
\hline & Sweden & $-0.306^{* * * * *}$ & 0.023 & $-0.277 * * * *$ & 0.024 \\
\hline & Pseudo $R^{2}$ & \multicolumn{2}{|c|}{0.116} & \multicolumn{2}{|c|}{0.120} \\
\hline & $N$ & \multicolumn{4}{|c|}{22,964} \\
\hline \multirow{6}{*}{$25-54$} & Denmark & $0.422 * * * *$ & 0.036 & $0.418^{\text {******⿲二丨匕 }}$ & 0.038 \\
\hline & Finland & -0.810 ***** & 0.030 & $-0.667 * * * *$ & 0.039 \\
\hline & Norway & $0.632 * * * *$ & 0.040 & 0.459 & 0.049 \\
\hline & Sweden & -0.244 ***** & 0.028 & -0.210 ***** & 0.029 \\
\hline & Pseudo $R^{2}$ & 0.133 & & & \\
\hline & $N$ & \multicolumn{4}{|c|}{15,115} \\
\hline
\end{tabular}

Note: The period for Denmark is 2000-2006. Significance probabilities for the coefficients: ${ }^{* * *} p<0.00$ I, $* * p<0.0$ I, ${ }^{*} p<0.05$.

Controls regarding gender, age, educational level, area of origin, industry, occupation, and working time are conducted in model I, while relative county unemployment levels and annual national changes in unemployment levels are also added in model 2. 
Table 6 Country rankings based on Tables 3-5, 19-63 years: model 2.

\begin{tabular}{lcccc}
\hline & $\begin{array}{c}\text { From unemployment to } \\
\text { permanent rather than } \\
\text { temporary contract }\end{array}$ & $\begin{array}{c}\text { From temporary } \\
\text { employment to } \\
\text { unemployment }\end{array}$ & $\begin{array}{c}\text { From permanent } \\
\text { to unemployment }\end{array}$ & $\begin{array}{c}\text { From temporary } \\
\text { to permanent } \\
\text { employment }\end{array}$ \\
\hline Denmark & 2 & 1 & 1 & 2 \\
\hline Finland & 3 & 2 & 2 & 4 \\
\hline Norway & 1 & 4 & 4 & 1 \\
\hline Sweden & 4 & 3 & 3 & 3 \\
\hline
\end{tabular}

Summarizing the main cross-country results from Tables 3-5 in Table 6, the results show that Denmark, with a combination of lax regulation of both permanent and temporary contracts, has the second highest transition rate into permanent employment, while having the highest transition rates into unemployment from both permanent and temporary employment. Denmark also has the second highest transition rate from temporary into permanent contracts. Norway, with a combination of strict regulation of both permanent and temporary contracts, has the highest transition rates from unemployment into permanent employment, and the highest transition rates from temporary to permanent employment. Further, the transition rates from permanent and temporary employment to unemployment is lowest in Norway, making the Norwegian model seem like an integrating, employee-friendly, labor market. In the other end, we find Sweden, with the highest transition rate from unemployment to temporary employment, and comparatively low (third) transition rates from temporary to permanent contracts. While so, the transition rates out of permanent and temporary jobs are lower in Sweden than in Denmark and Finland, a result of the fact that the overall mobility from employment to unemployment is comparatively low in Sweden (Berglund and Furåker, 2011: 125). Combined, the Swedish results indicate that such a model results in a layer of temporary employees who do not move into permanent jobs, while not experiencing lower job security. The Finnish results are rather comparable to the Swedish, albeit with even lower mobility rates from temporary to permanent contracts.

\section{Discussion and conclusion}

Investigating whether differences in permanent and temporary employment regulations make an impact on the transition patterns into the labor market for unemployed individuals, the results in this study show that unemployed individuals to a much higher extent enter the labor market through temporary rather than permanent contracts in Sweden and Finland, compared with Denmark and Norway, following the expectations in hypothesis 1 . Berglund and Furåker (2011) show that the mobility rates from unemployment into employment are highest in Norway, followed by Denmark. Therefore, the Nordic countries with the highest overall mobility into the labor market also have the highest share of transitions through permanent employment. Since temporary contracts 
are known to be of inferior quality, we may speak of a higher degree of labor market segmentation into the labor market in Sweden and Finland, combining strict regulation of permanent contracts with lax regulation of temporary contracts, than in Denmark and Norway, which does not. Regarding hypothesis 2, the Danish results follow the expectations. The risk of making a transition from temporary employment to unemployment is highest there, as the hiring risk is lower.

Different within-country studies have pointed to patterns of mobility from unemployment to temporary or permanent employment, and further whether temporary employees stay employed and become integrated into permanent contracts. This comparative study shows the relative difference in transition rates between the Nordic countries and pinpoints a much stronger tendency toward a segmented labor market in Finland and Sweden, with well-off permanent employees combined with a segment of temporary employees who are not integrated into permanent employment in the same degree as in Denmark and Norway. Gash (2008) found the strictest regulated country in her study, Germany, to integrate temporary employees into permanent contracts to a higher degree than Denmark, the UK, and France. The results here point in the same direction, with the strictest country with regard to permanent employment protection integrating temporary employees to a higher degree. While neoclassical economics assume that lax regulation of permanent and temporary contracts provides higher mobility and better possibilities for permanent (insecure) employment, this article shows that Norway, a rather strictly regulated labor market, provides the highest probabilities for getting permanent (secure) rather than temporary employment. Further, we find that Norway shows the highest transition rates from temporary to permanent employment, followed by Denmark, with a lax and lax regulation. As such, proponents of deregulating into lax EPL are not supported by the results in this article. Instead, the results indicate that strict regulations are able to bring unemployed individuals into the labor market through safe, permanent employment contracts.

While deregulation through laxer regulation of temporary contracts has been put forward as a way to deregulate labor markets while keeping the jobs of insiders secure, the transition patterns in the lax model (Denmark) come out with the "second best" results, as the transition rate from unemployment into temporary employment is better than in Sweden and Finland, and while the transition rate from temporary employment to unemployment is high in Denmark, those who stay employed move into permanent contracts. Therefore, this study indicates that when discussing labor market integration, regulation of the labor market in a strict or a lax mode may function better than deregulating through laxer regulations of temporary contracts. Further, the proponents of lax regulation of temporary contracts claim that temporary contracts have a redeeming effect in providing a bridge into the labor market. This claim is not supported by the results in this study, as temporary employees are becoming unemployed to a higher degree in Sweden and Finland than in Norway. While one indicator of the labor market integration of temporary employees is whether or not temporary employees become unemployed over time, moving from temporary to permanent contracts is another indicator. The transition rates from temporary to permanent employment contracts are lowest in Finland and Sweden, contrary to expectations by proponents of lax temporary employment regulation. It seems as though unemployed individuals in these labor markets to a larger extent become employed in secondary, temporary positions that it is difficult to move away from, pointing toward labor market segmentation, thus supporting hypothesis $2 \mathrm{~b}$. 
What can explain these clear differences in transition patterns in and out of the labor market? While the lax regulation of permanent contracts in the Danish labor market may provide companies with numerical flexibility, reducing the need for an internal, secondary group of employees with temporary contracts, the strict permanent regulation coupled with rather lax regulation of temporary employees seen in Finland and Sweden may have bred the ground for an insider-outsider labor market, where employers to a higher degree find it suitable to organize their numerical flexibility through a secondary group of temporary employees, in line with the ideas of Atkinson (1984). If so, this type of flexibility should perhaps have materialized itself in higher transition rates into unemployment, which could have been expected if this were the case. In Norway, the strict rules limit the possibilities of using temporary employees in order to enhance numerical flexibility, also at least partly explaining the low transition rates from temporary contracts to further temporary contracts or unemployment. Further, the strict regulation of permanent employment combined with the limited possibilities of using temporary employees may also explain the high level of transitions from temporary to permanent employment contracts in Norway. Since the hiring risks increase when permanent contracts are strictly regulated, the temporary contracts may to a higher degree than in the other countries function as a screening device, where temporary positions de facto function as a probationary contract before the employee is hired permanently. While such use is strictly regulated, and difficult to orchestrate by the employer when initiating a temporary employment contract, in positions where temporary employees substitute for employees on maternity leave or in other temporary positions within the same company, the employee holding the position permanently sometimes does not return. In such cases, the temporary employee holding the position may be permanently employed. Further, as there are relatively few temporary positions in Norway, this might also increase the likelihood of making a transition into a permanent position in itself.

We have controlled for unemployment levels and changes in unemployment levels, and tried to rule out the effect of institutional differences regarding labor market transitions among young and those heading toward retirement by also studying the individuals in their prime age as a group. Such explanations can therefore mostly be ruled as. Still, while it is possible that the Norwegian mix between strict permanent and strict temporary employment regulation does not lead to labor market segmentation, it is possible that the extraordinary high employment rates and low unemployment level in Norway at the time of the study, with close to full employment, reduced the chance of labor market segmentation. It could be that the control used does not remove the full impact of the economic boom in the Norwegian labor market. Still, Skollerud (1997) found a high degree of transitions from temporary to permanent employment also during the economic downturn in Norway during 1989-1993, indicating that the finding is not just an effect of high labor demand. In addition, while there are clear differences in transition patterns from one year to the next, it could be that the low transition pattern from temporary to permanent employment may change somewhat if studied over a longer time span than was available to us.

The consequences of EPL per se could not be measured directly, hence the results may be influenced by differences in the UB system or in the way dismissals and hiring of temporary employees are handled at the company level. While such measurement errors cannot be ruled out, the results in the study are robust, as they all point in the same direction, away from the idea that a combination of strict permanent and lax temporary 
regulation may integrate unemployed and temporary workers in the labor market and away from the neoclassical idea of lax regulation as the way to integrate unemployed and temporary employees.

Since the years 2000-2006, the Nordic countries have faced a financial crisis, followed by economic turbulence and lower economic growth. While the impact of the crisis has varied between the Nordic countries (Jochem, 2011; Mjøset, 2011), a topic for further studies would be to investigate whether the consequences of differences in regulations, and the transition patterns observed, are different during periods with low or no economic growth.

\section{Acknowledgments}

The author thanks the Norwegian research council's research program on welfare, working life and migration (VAM) for financing the study.

\section{References}

Andersen T, Haarh J, Hansen ME, et al. (2008) Job mobility in the European Union: Optimising its social and economic benefits. Copenhagen: Danish Technological Institute.

Atkinson J. (1984) The flexible firm and the shape of jobs to come. Labour market issue. Oxford: The Trade Union Research Center, Ruskin College.

Barth E, Moene KO and Wallerstein M. (2009) Likhet under press: utfordringer for den skandinaviske fordelingsmodellen [Equality under pressure: Challenges for the Scandinavian model of distribution], Oslo: Pensumtjeneste.

Bentolila S and Bertola G. (1990) Firing costs and labour demand: How bad is eurosclerosis? Review of Economic Studies 57: 381-402.

Berglund T, Aho S, Furåker B, et al. (2010) Labour market mobility in Nordic welfare states. TemaNord. 2010: 515 Copenhagen: Nordic Council of Ministers.

Berglund T and Furåker B. (2011) Flexicurity institutions and labour market mobility. The International Journal of Comparative Labour Law and Industrial Relations 27: 111-127.

Bertola G, Blau FD and Kahn LM. (2007) Labor market institutions and demographic employment patterns. Journal of Population Economics 20: 833-867.

Blanchard O and Landier A. (2002) The perverse effects of partial labour market reform: Fixed-term contracts in France. Economic Journal 112: F214-F244.

Blanchard O and Portugal P. (2001) What hides behind an unemployment rate: Comparing Portuguese and U.S. labor markets. The American Economic Review 91: 187-207.

Boje TP. (1986) Segmentation and mobility: An analysis of labour market flows on the Danish labour market. Acta Sociologica 29: 171-178.

Booth AL, Francesconi M and Frank J. (2002) Temporary jobs: Stepping stones or dead ends? Economic Journal 112. F189-F213.

Burroni L and Keune M. (2011) Flexicurity: A conceptual critique. European Journal of Industrial Relations 17: 75-91.

Chung H. (2005) Different paths towards flexibility, deregulated employment protection or temporary employment? ESPAnet conference: Making social policy in the postindustrial age. University of Fribourg, Switzerland. September 22-24, 2005. MPRA Paper No. 2396: Online at http://mpra.ub.uni-muenchen.de/2396/. 
DiPrete TA, Goux D, Maurin E, et al. (2001) Institutional determinants of employment chances. The structure of unemployment in France and Sweden. European Sociological Review 17. 233-254

Dølvik JE, Goul Andersen J and Vartiainen J. (2011) The Nordic social models: Crisis, consolidation and transformation. Minisymphosium "European Social Models in the Face of Global Economic Crisis”. The Council for European Studies Conference, Barcelona, June 20-22, 2011.

Edlund J and Grönlund A. (2008) Protection of mutual interests? Employment protection and skill formation in different labour market regimes. European Journal of Industrial Relations 14: 245-264.

Erixon L. (2010) The Rehn-Meidner model in Sweden: Its rise, challenges and survival. Journal of Economic Issues 44: 677-715.

Esping-Andersen G. (1990) The three worlds of welfare capitalism. Cambridge: Polity Press.

Esping-Andersen G. (2000) Who is harmed by labour market regulations? In: Esping-Andersen $\mathrm{G}$ and Regini M (eds) Why deregulate labour markets? Oxford: Oxford University Press: 66-98.

Esping-Andersen G and Regini M. (2000a) Introduction. In: Esping-Andersen G and Regini $\mathrm{M}$ (eds) Why deregulate labour markets? Oxford: Oxford University Press: 1-7.

Esping-Andersen G and Regini M. (2000b) Why deregulate labour markets? Oxford: Oxford University Press.

Feldmann H. (2003) Labor market regulation and labor market performance: Evidence based on surveys among senior business executives. Kyklos 56: 509-540.

Gangl M. (2003) The only way is up?: Employment protection and job mobility among recent entrants to European labour markets. European Sociological Review 19. 429-449.

Gangl M, Müller W and Raffe D. (2003) Conclusions: Explaining cross-national differences in school-to-work transitions. In: Müller W and Gangl M (eds) Transition from education to work in Europe. The integration of youth into EU labour markets. Oxford: Oxford University Press: 277-305.

Gash V. (2008) Bridge or trap? Temporary workers transitions to unemployment and to the standard employment contract. European Sociological Review 24: 651-668.

Giesecke J and Groß M. (2003) Temporary employment: Chance or risk? European Sociological Review 19: 161-177.

Goul Andersen J. (2007) Ældrepolitikken og velfærdsstatens økonomiske udfordringer. Tilbagetrækning, pension og ældreservice i Danmark [Senior policies and the economic challenges of the welfare state. Withdrawl, pension and senior services in Denmark]. University of Aalborg, CCWS Working Paper no. 47.

Hagen T. (2003) Do fixed-term contracts increase the long-term employment opportunities of the unemployed? Mannheim: Center for European Economic Research.

Heckman J. (2007) Comments on Are protective labor market institutions at the root of unemployment? A critical review of the evidence by David Howell, Dean Baker, Andrew Glyn, and John Smitht. Capitalism and Society 2: 1-4.

Heckman J and Pages C. (2000) The cost of job security regulation: Evidence from Latin American labour markets. NBER Working Paper NO. 7773.

Hodson R and Kaufman RL. (1982) Economic dualism: A critical review. American Sociological Review 47: 727-739.

Howell DR, Baker D, Glyn A, et al. (2007) Are Protective labor market institutions at the root of unemployment? A critical review of the evidence. Capitalism and Society 2: 1-71.

Hult C and Edlund J. (2008) Age and labour market commitment in Germany, Denmark, Norway and Sweden. Work, Employment \& Society 22: 109-128. 
Håkansson K. (2001) Språngbräda eller segmentering? Et longitudinell studie av tidsbegränsat anställda [Stepping stone or segmentation? A longitudinal study of temporary employees]. Uppsala: IFAU.

Ibsen CL. (2011) Strained compromises? Danish flexicurity during crisis. Nordic Journal of Working Life Studies 1: 45-65.

Jensen CS. (2011) The flexibility of flexicurity: The Danish model reconsidered. Economic and Industrial Democracy 32: 721-737.

Jochem S. (2011) Nordic employment policies-Change and continuity before and during the financial crisis. Social Policy \& Administration 45: 131-145.

Kalleberg AL, Reskin BF and Hudson K. (2000) Bad jobs in America: Standard and nonstandard employment relations and job quality in the United States. American Sociological Review 65: 256-278.

Kalleberg AL and Sørensen AB. (1979) The sociology of labor markets. Annual Review of Sociology 5: 351-379.

Lazear EP. (1990) Job security provisions and employment. The Quarterly Journal of Economics 105: 699-726.

Levin H. (1998) Arbetslöshet, tidsbegränsade anställningar och rörlighet på arbetsmarknaden i 1990-talets Sverige [Unemployment, temporary employment and labour market mobility in Sweden during the 1990s]. Stockholm: Institutet för Social Forskning.

Magnusson L, Jørgensen H and Dølvik JE. (2008) The Nordic approach to growth and welfare: European lessons to be learned?: ETUI-REHS aisbl Brussels.

Meidner R and Rehn G. (1953) Trade unions and full employment. Report to the LO Congress in 1951. Stockholm: The Swedish Confederation of Trade Unions (LO).

Mjøset L. (2011) The Nordic varieties of capitalism. Bingley: Emerald Group.

Muffels R and Luijkx R. (2008) Labour market mobility and employment security of male employees in Europe: "trade-off" or "flexicurity"? Work Employment and Society 22: 221-242.

Nergaard K. (2004) Atypisk arbeid. Midlertidige ansettelser og deltidsarbeid i Norge [Atypical work. Temporary employment and part time work in Norway]. Oslo: FAFO, Rapport 430.

Nickell S. (1997) Unemployment and labor market rigidities: Europe versus North America. The Journal of Economic Perspectives 11: 55-74.

Nätti J. (1993) Temporary employment in the Nordic countries: A “trap" or a "bridge"? Work, Employment \& Society, 7: 451-464.

OECD (1994) The OECD job study: Part I and II. Paris: OECD.

OECD (2004) Employment outlook. Paris: OECD.

OECD (2006) Employment outlook. Paris: OECD.

OECD (2007) Benefits and wages. Paris: OECD.

OECD (2008) Employment outlook. Paris: OECD.

Olofsson J and Wadensjö E. (2007) Ungdomar, utbildning och arbetsmarknad i Nordenlika men ändå olika [Youth, education and the Nordic labour market-Equal but still unequal]. Stockholm: FAS: Forskningsrådet for arbeidsliv och socialvetenskap.

Ozaki M. (1999) Negotiating flexibility: The role of the social partners and the state. Geneva: ILO.

Palier B and Thelen K. (2010) Institutionalizing dualism: Complementarities and change in France and Germany. Politics \& Society 38: 119-148.

Polavieja JG. (2003) Temporary contracts and labour market segmentation in Spain: An employment-rent approach. European Sociological Review 19: 501-501.

Polavieja JG. (2006) The incidence of temporary employment in advanced economies: Why is Spain different? European Socialogical Review 22: 61-78.

Ragin CC. (1987) The comparative method: Moving beyond qualitative and quantitative strategies. Berkeley, CA: University of California Press. 
Regini M. (2000) The dilemmas of labour market regulation. In: Esping-Andersen G and Regini M (eds) Why deregulate labour markets? Oxford: Oxford University Press: $11-29$.

Rubery J and Grimshaw D. (2003) The organization of employment : An international perspective. Basingstoke: Palgrave Macmillan.

Skedinger P. (2010) Employment protection legislation: Evolution, effects, winners and losers. Cheltenham: Edward Elgar.

Skollerud K. (1997) Er midlertidig ansatte og deltidsansatte marginalisert på arbeidsmarkedet? [Is temporary employees and part-time workers marginalized on the labour market?]. Søkelys på arbeidsmarkedet 14: 107-111.

Svalund J, Bergström GC, Dølvik JE, et al. (2013) Stress testing the Nordic models: Manufacturing labour adjustments during crisis. European Journal of Industrial Relations Forthcoming fall 2013.

van den Berg A. (2008) Flexicurity, theory, practice or rhetoric? Employment policy-From research to reform. Aalborg University, CARMA.

Venn D. (2009) Legislation, collective bargaining and enforcement: Updating the OECD employment protection indicators. Available at: www.oecd.org/els/workingpapers.

\section{End notes}

1 In 2004, the duration was reduced from 36 to 24 months.

2 The table was slightly changed April 2013 due to mistakes during the layout process. The table originally published partially consisted of three models, which was confusing and not intended. The change does not influence the content of the article in any way. 